\title{
Obituario
}

\section{IN MEMORIAM DR. JUAN ALBERTO ARAGÓN B.}

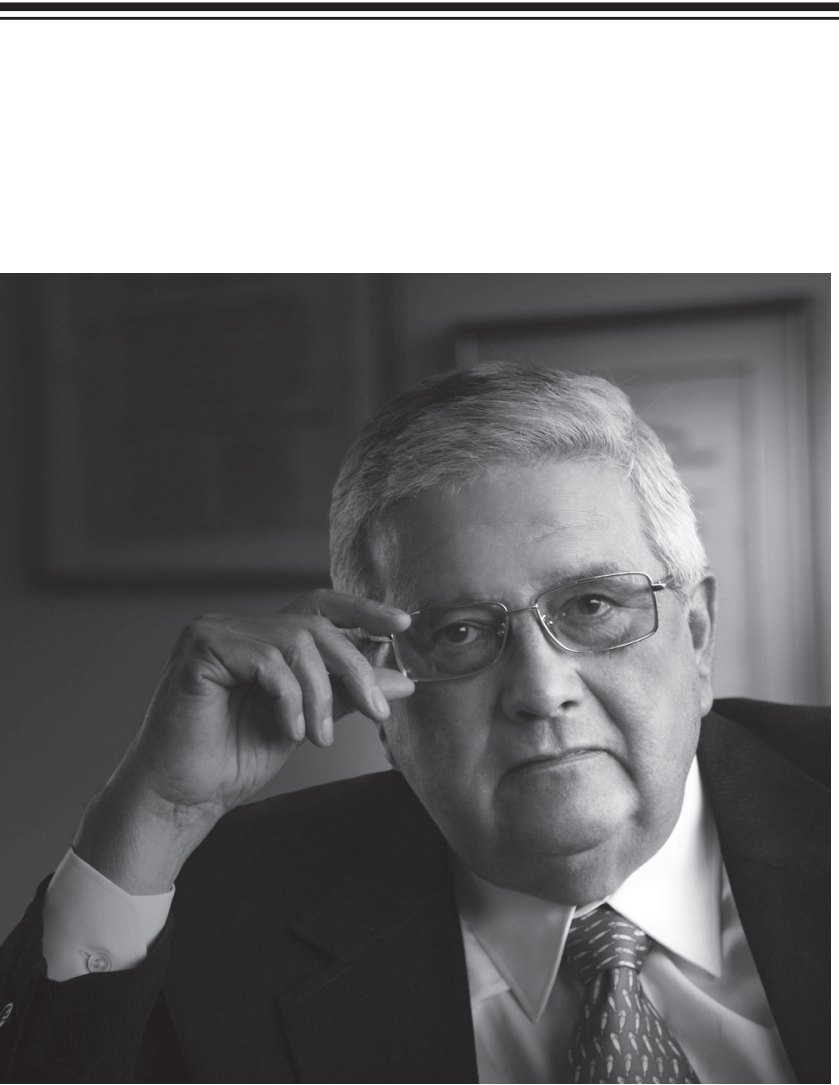

El psicólogo Juan Alberto Aragón nació en la ciudad de Popayán, Colombia, y perteneció a una familia con una larga tradición intelectual. Fue nieto de Arcesio Aragón León, historiador, abogado y profesor universitario, miembro de la Real Academia de la Lengua Española, autor de diferentes obras y merecedor de la Cruz de Boyacá por su aporte a la educación y la cultura, e hijo de Víctor Aragón Pardo, también abogado, autor de diversas obras literarias que forman parte del acervo cultural del Cauca. Realizó sus estudios de pregrado y posgrado en el Instituto de Psicología de la Universidad de Varsovia, Polonia. Obtuvo el grado en el campo de la Psicología Clínica Experimental bajo la dirección del profesor Dr. Janusz Reykowski, fundador y primer director del Instituto de Psicología de la Academia Polaca de Ciencias; además, reconocido investigador en psicología social. De regreso a Colombia en 1971, una vez terminados sus estudios

\section{José Antonio Sánchez González \& Marithza Sandoval-Escobar}

de Psicología en Polonia, se vinculó al Departamento de Psicología de la Universidad Nacional. Comenzó allí a darle curso desde de esta institución a su vocación y talentos de gran científico, investigador y profesor.

A lo largo de nuestra vida personal y académica consideramos un gran honor el haber conocido y tratado al Dr. Juan Alberto Aragón y por consiguiente haber establecido con él estrechos lazos de admiración, amistad y colegaje. En cuanto al contenido de esta breve nota, nos limitaremos a una concisa semblanza de este gran intelectual, señor y amigo que nos honró con su amistad y con la posibilidad de colaborar con él en el desarrollo de una gran Institución para la Educación Superior de Colombia, como es la Fundación Universitaria Konrad Lorenz, enlutada ahora por su lamentable deceso, pero lo suficientemente consolidada para darle el debido curso a la Misión que le asignó su Fundador.

Su labor docente se desarrolló principalmente en los campos de la Filosofía y Lógica de la Ciencia, Psicología Clínica Experimental, Psicología Evolutiva y Psicología de la Personalidad. En 1972 fue nombrado Profesor Asociado a la Escuela de Graduados de la Universidad Pedagógica Nacional, desempeñándose fundamentalmente en el campo de la Psicología del Aprendizaje y Metodología de la Investigación. En agosto de 1973 asumió la Dirección del Centro de Investigaciones de la Universidad Pedagógica Nacional-U.P.N, y allí lideró el desarrollo del Laboratorio de Psicología Experimental y del Aprendizaje, uno de los primeros creados en Colombia. Simultáneamente se desempeñó como profesor de Filosofía de la Ciencia, Psicología del Lenguaje y del Pensamiento, así como de Técnicas de la Modificación de la Conducta, en la U.P.N. y en el Departamento de Psicología de la Universidad de los Andes. 


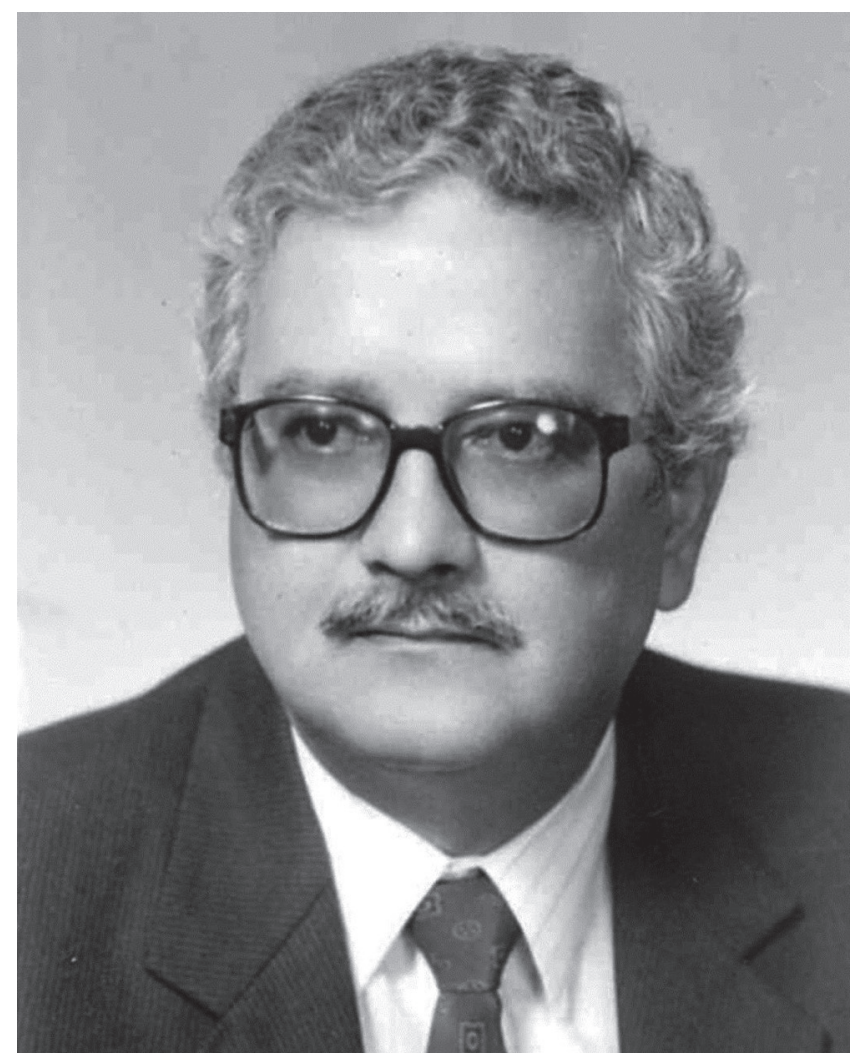

Aquella década de los setenta en Colombia fue una época de gran exacerbación ideológica por parte de diferentes grupos políticos, lo que reflejaba las transformaciones sociales que se estaban presentado en diversos países de América Latina. El interés del Dr. Juan Alberto Aragón fue intentar mostrar a estos grupos de intelectuales que el gran objetivo de la ciencia es acercarse al conocimiento de la realidad en sus diferentes niveles y formas de complejidad, con el objetivo de elevar la calidad de la vida de los seres humanos y la conservación de la vida en nuestro planeta tierra. Ello implica situarse honestamente más allá de los prejuicios, las diversas formas de intolerancia y los reduccionismos. La extraordinaria biblioteca personal del Dr. Aragón reflejaba bien todos estos ideales de conocimiento desde la historia de la ciencia y sus senderos epistemológicos, hasta los desarrollos más recientes de la física cuántica y de las teorías económicas, así como de política, sociología y otras ciencias sociales, conjuntamente con la genética, ciencias que ocuparon un importante lugar en su lista de lectura. El Dr. Aragón siempre se interesó por los campos de investigación actuales y abordó complejas lecturas intradisciplinarias, interdisciplinarias, transdisciplinarias y metadisciplinarias. Algunos tuvimos el inmenso placer de analizar con él estos complejos problemas en su oficina de
Rector (siempre de puertas abiertas) al lado de una agradable taza de café. En sus tertulias, el Dr. Aragón y José Antonio Sánchez evocaban estas palabras del poeta Thomas Stearns Eliot: “¿Cuándo recuperaremos la sabiduría que estamos perdiendo con la información?”

A partir de 1974 dirigió su atención hacia la investigación curricular desde el Instituto Colombiano de Pedagogía ICOLPE, donde fue nombrado subdirector. Como se puede observar en su obra (Teorías de la Personalidad, 1971; Procesos Heurísticos de Solución de Problemas, 1971; Psicología y Procesos de Auto-regulación, 1974; Efectos del Comportamiento del Maestro Sobre la Conducta Académica de los Alumnos, 1973; Hacia una Fundamentación de la Tecnología Educativa, 1973; Técnicas de Terapia Familiar, 1975; Estructura y Funciones del Subsistema de Investigación de la Universidad Nacional Abierta, 1977; Técnicas de Auto-Control del Comportamiento de Estudios, 1977), sus intereses investigativos se centraron en la tecnología de la enseñanza y otras aplicaciones del análisis del comportamiento al mejoramiento de la calidad de vida humana, en particular en ambientes educativos. En sus publicaciones se puede apreciar la convicción de que la educación debe centrarse en el aprendizaje del estudiante y el diseño de contextos que lo faciliten, a través de la enseñanza programada, el aprendizaje por objetivos y la investigación pedagógica como elemento central del proceso enseńanza - aprendizaje.

Sus estudios sobre educación lo llevaron no sólo a plantear una línea de investigación en psicología educativa desde una perspectiva científica, sino a estructurar un proyecto educativo donde primaran los intereses genuinos por el conocimiento y la ciencia. Por sus ideales liberales, siempre pensó que todos tenían derecho a una excelente educación y que las ofertas disponibles debían ser congruentes con las difíciles circunstancias económicas y sociales que enfrentaba el país. El Dr. Aragón se propuso entonces velar por la consolidación de una comunidad que trabajara por la educación desde una perspectiva científica; en todas las instituciones de educación en las cuales trabajó se interesó por asegurarles a los estudiantes los más elevados perfiles de formación para materializar los ideales de equidad y justicia social. Siempre pensó que una buena educación debía conducir a las personas a ser competentes como ciudadanos con una profunda consciencia ética, gran cultura general universalizante para la comprensión de los tiempos modernos y la inserción social como ciudadanos del 
mundo, solidarios con la humanidad y capaces de participar en procesos de innovación y solución de problemas. La memoria y la herencia que ha dejado el Dr. Juan Alberto Aragón, el profesor y educador, será imperecedera.

Entre 1979 y 1980 concibió la Fundación Universitaria Konrad Lorenz, proyecto que inicia con su esposa, la Dra. Sonia Fajardo Forero en el año 1981 y que es el fruto de su profunda complicidad afectivo-profesional. Hoy en día es su esposa quién mantiene vivo su legado y lo comparte con una gran familia de egresados, estudiantes, docentes y colaboradores. Desde entonces y hasta el año de 1999, el Dr. Juan Alberto Aragón ejerció como Rector de la Konrad Lorenz, cargo que reasumió en marzo de 2003 hasta el año 2009. Fue también Presidente del Consejo Superior entre los años 1994 y 2013.

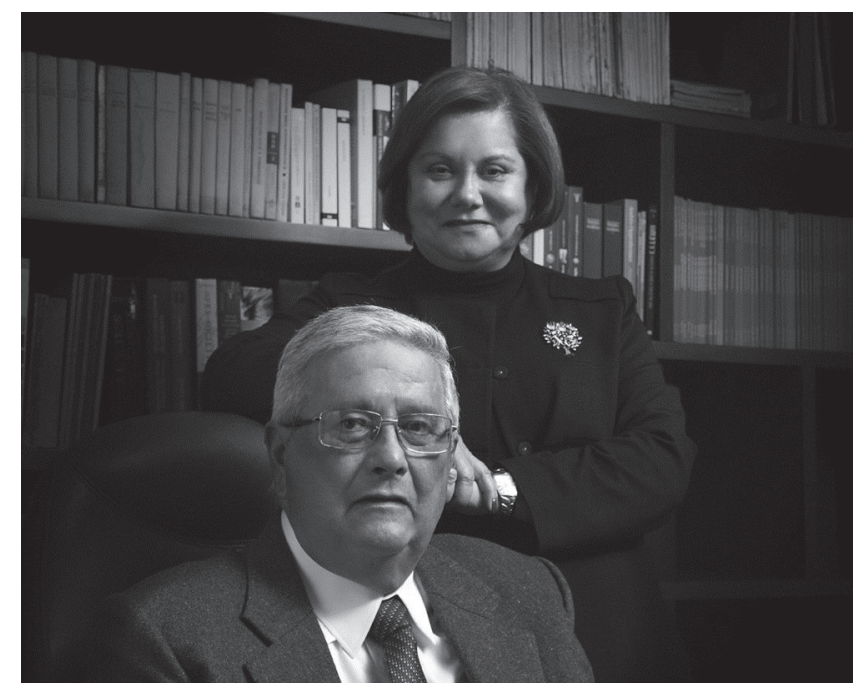

Se han suscitado muchos interrogantes alrededor de las razones que existieron para denominar "Konrad Lorenz" a su proyecto educativo. Como en muchos aspectos de su vida, dicha elección refleja la admiración que experimentó por la ciencia honesta, innovadora y humana. Se debe recordar que en noviembre de 1972 les fue concedido el premio Nobel de Medicina a los tres grandes fundadores de la etología moderna Konrad Lorenz (Austria) Nicolás Timbergen (Holanda) y Karl Von Frisch (Alemania). La Academia Sueca citó como motivación principal para este premio el reconocimiento de que "ellos abrieron una gran puerta para el estudio de las bases biológicas del comportamiento de los animales, incluidos los seres humanos". El Dr. Aragón se sintió muy complacido y entusiasmado por la concesión de este galardón a tres biocientíficos del comportamiento, y decidió rendirles homenaje al dar a esa nueva institución el nombre de Konrad Lorenz.

Además de la biología del comportamiento humano y animal, experimentó una profunda predilección por la filosofía de la ciencia y sus configuraciones histórico - epistemológicas. En algún momento de su carrera se declaró simpatizante de la filosofía empírico-analítica, pero mantuvo su mente abierta a los nuevos desarrollos de la filosofía moderna y los abordó de manera crítica y constructiva. El Dr. Aragón admiraba de especial manera al gran pensador Mario Bunge, Director por varios años del Departamento de Filosofía de la Ciencia de la Universidad de McGill en Montreal. En el año 1988, con el apoyo de la Asociación de Instituciones Universitarias de Colombia, invitó al Profesor Bunge como conferencista principal de un evento que tuvo lugar en el Hotel Tequendama. Luego de superar los múltiples inconvenientes que en esa época implicaban las visitas desde el extranjero de personas tan ilustres, el Dr. Aragón pudo comprobar con satisfacción y mucha emoción que el reconocimiento no solo provenía del sector académico de nuestro país. Los mismos funcionarios de inmigración rindieron honores al autor de "La Ciencia, su Método y su Filosofía” al concederle una visa de cortesía. El Dr. Mario Bunge fue el primero de muchos visitantes ilustres que fueron invitados a la Konrad Lorenz por el Dr. Aragón, siempre con el ánimo de fortalecer la formación tanto de estudiantes como de docentes, y aportar a la disciplina desde una perspectiva científica.

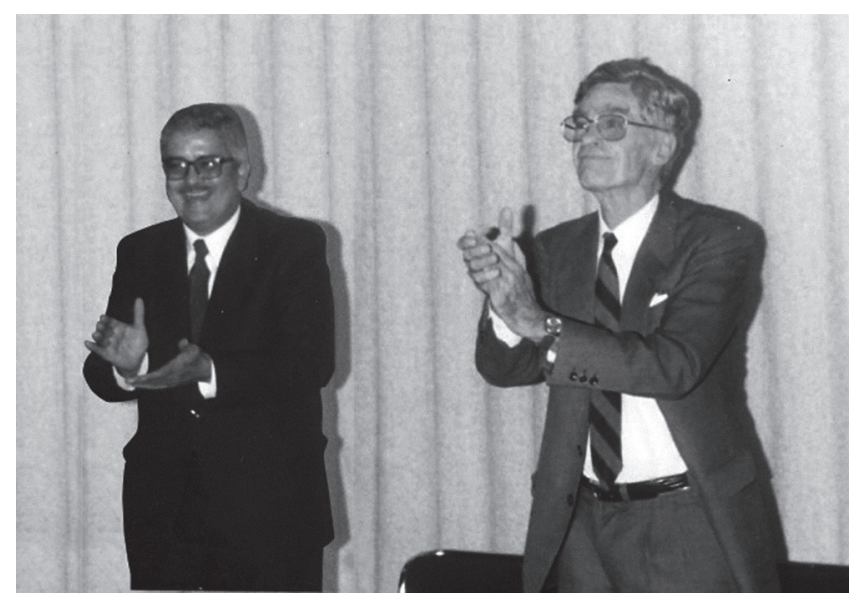

Siempre admiró las publicaciones científicas en las cuales primara la objetividad y se valorara la calidad de la investigación como criterio de aceptación. Por esto, en el año de 1992 crea la revista Suma Psicológica y le asigna la misión 
de divulgar el conocimiento científico en el campo de la psicología a partir de las condiciones de calidad, pertinencia e impacto de la investigación. De igual forma, en el 2007 gestiona la adquisición de la Revista Latinoamericana de Psicología (rlp), uno de los iconos de la ciencia psicológica colombiana, convencido de que la Institución que dirigía podría mantener los estándares de calidad, objetividad e ideales que caracterizan dicha publicación; y así fue. Hoy en día la Konrad Lorenz Fundación Universitaria edita estas dos importantes revistas, destinando los recursos humanos, técnicos y financieros necesarios para asegurar su sostenibilidad y aporte social al desarrollo de la disciplina en la región.

Todas estas vivencias se han transferido a la Misión y valores de la Konrad Lorenz, no sólo porque fue el creador de este proyecto educativo, sino porque muchos de los retos que inspiraron su consolidación siguen vigentes. Frente a una sociedad globalizada y unas problemáticas sociales agudizadas a través de las generaciones y un desarrollo académico-científico apenas incipiente en Latinoamérica, es cada vez más importante que sean los científicos e intelectuales quienes emprendan la tarea de aportar al cambio social. A pesar de su partida, sigue en alto el ideal de que la ciencia es el camino hacia el cambio social, así como la valoración por la tecnología y la educación como vehículos para el logro de dichos cambios.
Su familia, sus amigos, sus colegas, subalternos y estudiantes, siempre recordarán que el Dr. Juan Alberto Aragón fue una persona amable, sencilla, perseverante y afectuosa. En diversas circunstancias mantuvo su criterio a pesar de las modas y de los cambios políticos; fue un hombre íntegro, para quien cada persona era un cúmulo de posibilidades. Sabía comprender y evaluar diferencialmente las competencias, disposiciones y talentos de cada individuo. Siempre mesurado y justo, sabía reconocer valores y estimular debidamente a cada uno. Sus exquisitos modales y sentido de la justicia realzaban en él la credibilidad que se merecía y la autoridad que suscitaba en cada uno de sus colaboradores, la comunidad de los docentes y los estudiantes. Profesaba la buena fe en la humanidad y se dedicó toda una vida a ejercer una labor solidaria con el país y con la región. Despedimos a un gran hombre y un entrańable amigo, sus huellas seguirán presentes en el camino cotidiano de todos nosotros quienes fuimos formados bajo su filosofía.

"Las empresas humanas se dignifican no por ser perfectas e inalterables -y nunca lo son- sino por sus metas, por sus objetivos y por la decisión tenaz de la autocritica y el mejoramiento constante." Dr. Juan Alberto Aragón.

Ceremonia de graduación de la primera promoción de la Facultad de Psicología, julio -1987. 


\section{IN MEMORIAM DR. JUAN ALBERTO ARAGÓN B.}

\section{José Antonio Sánchez González \& Marithza Sandoval-Escobar}

Psychologist Juan Alberto Aragón was born in Popayan, Colombia, and he belonged to a household which had a long intellectual tradition. Dr. Aragón was the grandchild of Arcesio Aragón León, a historian, lawyer and University professor who authored a number of works and was awarded the "Cruz de Boyacá" medal for his contributions to education and culture. Dr. Aragón's father was Victor Aragón Pardo; he was also a lawyer and he too authored a great many literary works which currently make part of the Cauca region's cultural heritage. Juan Alberto Aragón completed his undergraduate and graduate studies at the University Of Warsaw Institute Of Psychology. He graduated in the field of Experimental Clinical Psychology under the guidance of Professor Dr. Janusz Reykowski, founder and first director of the Institute of Psychology - Polish Academy of Sciences, and also a renowned researcher in social psychology. Back in Colombia in 1971, and after completing his studies in Psychology in Poland, he started working with the Department of Psychology at Universidad Nacional, where I was working at the time. Dr. Aragón began to exploit his vocation and talents as a great scientific researcher and professor at this institution.

Throughout our personal and academic life, we are honored to have been acquainted to Dr. Juan Alberto Aragón; indeed, we established close ties based on admiration, friendship and collegiality. As for the contents of this brief note, we shall limit ourselves to a concise portrayal of this great intellectual and friend who honored us with his friendship and the possibility of working with him in the development of a great institution for Higher Education in Colombia, such as Fundación Universitaria Konrad Lorenz, who now mourns for his most lamentable death. However, Dr. Aragon left a well-established University which shall surely pursue the mission assigned to it by its founder.
Dr. Aragon's teaching was mainly in the fields of Philosophy and Logic of Science, Experimental Clinical Psychology, Developmental Psychology and Personality Psychology. In 1972 he was appointed Associate Professor at the Graduate School of Universidad Pedagógica Nacional, working primarily in the field of Psychology of Learning and Research Methodology. Dr. Aragon became the manager of the Research Center of Universidad Pedagógica Nacional in August 1973, where he led the development of the Laboratory of Experimental Psychology and Learning, one of the first think tanks created in Colombia. Simultaneously, Dr. Aragon served as Professor of Philosophy of Science, Psychology of Language and Thought and Techniques of Behavior Modification at Universidad Pedagógica Nacional and the Department of Psychology at Universidad de los Andes.

The Seventies in Colombia were times of great ideological exacerbation by different political groups, and this reflects the social changes that were introduced in various countries of Latin America. Dr. Juan Alberto Aragón's interest was trying to show these groups of intellectuals that the ultimate aim of science is gaining knowledge of reality in its different forms and levels of complexity, with the aim of improving the quality of life of human beings and the preservation of life on our planet earth. This entails an honest look beyond prejudices, the various forms of intolerance and reductionism. The extraordinary personal library of Dr. Aragón well reflected these ideals of knowledge from the history of science and its epistemological paths to the most recent developments of quantum physics and economic theory and politics, including sociology and other social sciences together with genetics; these sciences occupied an important place in his reading list. Dr. Aragon was always interested in the fields of current research and took on complex intradisciplinary, 
interdisciplinary, and metadisciplinary readings. Some had the great pleasure to discuss these complex issues with him in his Chancellor's Office (which was always open), with a nice cup of coffee. In their talks, Dr. Aragón and José Antonio Sánchez evoked poet Thomas Stearns Eliot's words: "When shall we recover the wisdom we are losing with information?"

From 1974 onwards, Dr. Aragon turned his attention to curriculum research at Colombian Institute of Pedagogy - ICOLPE, where he was appointed Deputy Director. As can be seen in his work (Theories of Personality, 1971, Heuristic Problem Solving Processes, 1971, Psychology and Processes of Self-Regulation, 1974, Effects of Teachers' Behavior About Students' Academic Behavior, 1973 Towards Foundations of Educational Technology, 1973, Techniques of Family Therapy, 1975, Structure and Functions of Universidad Nacional's Open Research Subsystem, 1977, Self-Control Techniques in Academic Behavior, 1977), his research interests focused on technology education and other applications of behavior analysis to improve the quality of human life, particularly in educational settings. In his publications can appreciate the belief that education should focus on student learning and design contexts that facilitate it through programmed instruction, learning objectives and educational research as a central element of the teaching - learning process.

Dr. Aragón's studies on education led him not only to create a line of research in educational psychology from a scientific stance, but to structure an educational project where genuine interests for knowledge and science would prevail. By his liberal ideals, Dr. Aragon always thought that everyone had the right to excellent education, and the available supply should be consistent with the difficult economic and social circumstances the country faces. Dr. Aragon then undertook to ensure the consolidation of a community who would work with education from a scientific perspective. At all the educational institutions for which he worked he sought to assure students would form higher education profiles to realize the ideals of equity and social justice. Dr. Aragón always thought that a good education should lead to people being competent as citizens, with deep ethical awareness, great general universalizing culture for understanding modern times and social inclusion as citizens of the world, as well as solidarity with humanity and an ability to participate in innovation processes and problem solving. The memory and legacy left by Juan
Alberto Aragón, Professor and Educator, shall be everlasting. Between 1979 and 1980, Dr. Aragón conceived the creation of Fundación Universitaria Konrad Lorenz, a project which he began along with his wife Dr. Sonia Fajardo Forero, in 1981; this is also the result of their deep communion, both in the affective and professional realms. Since then and until 1999, Dr. Juan Alberto Aragón served as Chancellor of Konrad Lorenz University, and he resumed this position from March 2003 to the year 2009. He was also the President of the High Council from 1994 to 2013. Many questions have been raised about the reasons Dr. Aragón dubbed his educational project "Konrad Lorenz". As in many aspects of his life, this choice reflects the admiration Dr. Aragón felt for honest, innovative and human science. Let it not be forgotten that, in November 1972, the Nobel Prize for Medicine was awarded to the three great founders of modern ethology, Konrad Lorenz (Austria) Nicholas Tinbergen (Netherlands) and Karl Von Frisch (Germany). The Swedish Academy cited as the main motivation for this award the recognition that "they opened a big door for the study of the biological basis of behavior in animals, including human beings." Dr. Aragon was very pleased and excited by the granting of this award to three behavior scientists, and decided to pay homage to them by giving this new institution the name of Konrad Lorenz.

In addition to the biology of human and animal behavior, Dr. Aragon experienced a deep fondness for the philosophy of science and its historical - epistemological settings. He was a self-proclaimed supporter of empirical-analytical philosophy, but always kept an open mind with regard to the new developments of modern philosophy and approached them in a critical and constructive fashion. Dr. Aragón especially admired the great philosopher Mario Bunge, who served for several years as the Director of the Department of Philosophy of Science at McGill University in Montreal. In 1988, with the support of the Association of Colleges of Colombia, Professor Bunge was invited as keynote speaker for an event that took place at Hotel Tequendama. After overcoming the many problems which had to be faced at the time for visits of such illustrious persons from abroad, Dr. Aragon was pleased to see that admiration not only came from the academic sector of our country; the very immigration officers paid tribute to the author of "Science, Philosophy and its Method" by granting him an honorary visa to enter our country. Professor Mario Bunge was the first of many distinguished visitors invited to Konrad Lorenz University by Dr. Aragon, always seeking to strengthen 
educational processes both of students and professors, thus contributing to the discipline from a scientific standpoint.

Dr. Aragon was always fond of scientific publications which would prioritize objectiveness and value quality of research as a first and foremost criterion for acceptance. Pursuant to this, Suma Psicológica Journal was created in 1992, and its mission was that of disseminating scientific knowledge in the field of psychology based on quality, relevance and impact of research. Likewise, Dr. Aragón acquired Revista Latinoamericana de Psicología (rlp) in 2007; this one of the flagship Journals of psychology in Colombia. Dr. Aragón strongly believed that the Institution could perfectly measure up to the standards of quality, objectiveness and the goals pursued by this publication; and so it did. Fundación Universitaria Konrad Lorenz currently edits these two remarkably important journals, and allots the human, technical and financial wherewithal to ensure its sustainability and social contribution to the development of psychology in the region.

All these experiences have been transferred to the mission and values of Konrad Lorenz University, not only because he was the creator of this educational project, but because many of the challenges that inspired its consolidation still remain. Facing a global society and heightened social problems through academic-scientific generations who were just emerging in Latin America, it is increasingly important for scientists and intellectuals to undertake the task of contributing to social change. Despite his departure, the ideal that "science is the pathway to social change" still remains, as does the acknowledgement of technology and education as vehicles for achieving these changes.

His family, friends, colleagues, employees and students always remember that Dr. Juan Alberto Aragón was a kind, simple, persistent and loving person. In various circumstances he kept his discretion despite zest and political change and was always a man of integrity; every person was for him a wealth of possibilities. Dr. Aragon knew very well how to understand and differentially assess the skills, dispositions and talents of each individual. He was always thoughtful and fair; he acknowledged and fostered values. His exquisite manners and sense of justice highlighted the credibility he deserved, as well as the authority he gained in each of his employees, the community of professors and students. Dr. Aragon professed good faith in humanity and a lifetime devotion to the exercise of solidarity work with the country and the region. Farewell to a great man and a dear friend; his legacy shall linger in the everyday life of all of us who were trained under his philosophy.

"Human endeavors are dignified not by being perfect and unchangeable - and they never are - but by their goals, objectives and the outright decision to exercise self-criticism and constant improvement." Dr. Juan Alberto Aragon. Graduation ceremony of the first class School of Psychology, July -1987. 
